\title{
Current Role of Anti-Integrin Therapy in Inflammatory Bowel Disease
}

\author{
Kevin Winston*, Hasan Maulahela**, Lusiani***, Raditya Dewangga*, \\ Lazuardi G Ilhami* \\ ${ }^{*}$ Faculty of Medicine, Universitas Indonesia/Dr. Cipto Mangunkusumo General National Hospital \\ Jakarta \\ *Division of Gastroenterology, Department of Internal Medicine, Faculty of Medicine, Universitas \\ Indonesia/Dr. Cipto Mangukusumo General National Hospital, Jakarta

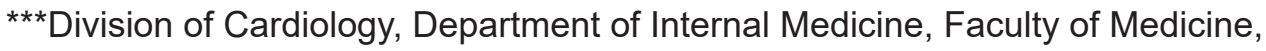 \\ Universitas Indonesia/Dr. Cipto Mangunkusumo National General Hospital, Jakarta
}

\begin{abstract}
Corresponding author:
Hasan Maulahela. Division of Gastroenterology, Department of Internal Medicine, Dr. Cipto Mangunkusumo General National Hospital. Jl. Diponegoro No. 71 Jakarta Indonesia. Phone: +62-21-3153957; Facsimile: +62-21-3142454. E-mail: hasan.maulahela@yahoo.com
\end{abstract}

\begin{abstract}
Inflammatory bowel disease (IBD) is a chronic inflammatory intestinal disorder with multifactorial etiology. Management of IBD is divided into conventional treatment and new treatment with biologic agents. The first biologic agents used for IBD was tumor necrosis factor (TNF)-inhibitor. However, TNF-inhibitor as a biologic agent has several limitations such as low rate of clinical response and systemic immunosuppressive side effects. Anti-integrin is a recently developed biologic agent which selectively inhibits leukocyte trafficking towards site of inflammation. The inhibition is caused by blocking the actions of integrin, a cell adhesion molecules (CAMs) that is necessary for leukocyte trafficking and leukocytes express specific integrin receptors for specific organs. Therefore, use of gut-specific anti-integrin agents in IBD can selectively prevent influx of leukocytes into the intestine to reduce inflammation without reducing immune function in other locations. As a result, gut-specific anti-integrin is hypothesized to have lower risk of infections and lower risk of malignancy than TNF-inhibitor while maintaining high therapeutic benefits, making anti-integrin a promising therapy for IBD in the future.
\end{abstract}

Keywords: Anti-integrin, inflammatory bowel disease (IBD), Crohn's disease (CD), ulcerative colitis (UC) leukocyte trafficking, biological therapy

\section{ABSTRAK}

Inflammatory bowel disease (IBD) adalah penyakit inflamasi kronis pada usus dengan etiologi multifaktorial. Tatalaksana IBD dibagi menjadi terapi konvensional dan terapi agen biologis. Agen biologis pertama yang digunakan untuk IBD adalah antagonis-TNF. Namun, antagonis-TNF sebagai agen biologis memiliki beberapa keterbatasan seperti tingkat respons klinis yang rendah dan efek samping imunosupresif sistemik. Anti-Integrin adalah agen biologis baru yang dapat secara selektif menginhibisi migrasi leukosit ke lokasi peradangan. Inhibisi ini disebabkan oleh blokade reseptor integrin yang berperan dalam migrasi leukosit. Leukosit memiliki reseptor integrin spesifik untuk setiap jaringan sehingga penggunaan agen anti-integrin spesifik usus pada IBD dapat secara selektif mencegah migrasi leukosit ke dalam usus tanpa menurunkan imunitas di jaringan lain. Oleh karena itu, anti-integrin spesifik usus dihipotesiskan memiliki risiko infeksi yang lebih rendah dan risiko keganasan yang lebih rendah bila dibandingkan dengan antagonis TNF. Selain itu anti-integrin tetap memiliki 
efek terapeutik yang tinggi. Kelebihan ini menjadikan anti-integrin sebagai terapi yang menjanjikan untuk IBD di masa mendatang.

Kata kunci: Anti-integrin, inflammatory bowel disease (IBD), penyakit Crohn, kolitis ulseratif, migrasi leukosit, agen biologis

\section{INTRODUCTION}

Inflammatory bowel disease (IBD) is an umbrella term that refers to two immune-mediated chronic intestinal inflammation, ulcerative colitis (UC) and Crohn's disease (CD). ${ }^{1}$ Worldwide, IBD has a variable incidence depending on the geographic areas. IBD mainly occurs at the highest incidence in Western Countries. However, there has been a rising incidence of IBD in Asia with several countries undergoing a more rapid increase than other countries. ${ }^{2}$ Possible mechanisms that explain rise of IBD in Asia include urbanization, westernization of diet, smoking, pollution, better sanitization, and better diagnostics tools recently made available. ${ }^{1,2}$

Current mainstay treatment of IBD is aimed at reducing intestinal inflammation and inducing clinical remission. ${ }^{1}$ Treating IBD with non-biological agents such as glucocorticoids and immunomodulators have provided symptomatic improvement in IBD patients, however, the disease progression is often still ongoing, causing stenosis, abscesses, fistulas, and extra-intestinal manifestations later on. ${ }^{1}$ The development of TNF-inhibitor as the first biologic agent represents a milestone for IBD therapy that can change IBD disease progression. However, advances in IBD mechanisms led to understanding that there are several other important pathways involved in IBD pathogenesis such as intestinal leukocyte trafficking and not all IBD patients are responsive to TNF-inhibitors. ${ }^{3}$ Anti-integrin are new biological agents that selectively inhibits leukocyte trafficking pathway towards target tissue. In this article, we aim to review intestinal leukocyte trafficking and the role of anti-integrin therapy as a new drug therapy for the treatment of IBD.

\section{NEED FOR NEW BIOLOGIC AGENT IN IBD}

The approval of the first TNF-inhibitor agent, infliximab for clinical use marks the beginning of biological therapy era in the late 1990s. ${ }^{4}$ Use of TNFinhibitor for IBD showed that a single cytokine block is sufficient to suppress intestinal inflammation and induce clinical remission in IBD. As a result, numerous next generation TNF inhibitors were developed for use in IBD such as adalimumab, golimumab, and certolizumab pegol with TNF-inhibitors then becoming gold standard treatment for moderate-severe IBD. Additionally, TNF-inhibitors has also been demonstrated to reduce hospital admission rates and provide quality of life improvement for IBD patients.

Despite the effectiveness of TNF-inhibitor agents in induction and maintenance of clinical remission when compared with conventional drugs, there are still approximately $10-30 \%$ of IBD patients exhibiting no clinical response to TNF-inhibitor therapy and around $60 \%$ of IBD patients given TNF-inhibitor fail to achieve clinical remission. ${ }^{5,6}$ Furthermore, some patients lose the response to TNF-inhibitor overtime due to formation of antidrug antibodies, resulting in the need to increase the dose overtime. ${ }^{7,8}$ It is speculated that TNF may actually not be the main cause of inflammation in some IBD patients as IBD is a very complex disease involving numerous mechanisms. ${ }^{9}$

Another important issue with TNF-inhibitors is the immunosuppressive systemic side effects, in which its prolonged use is associated with higher risk of serious infection, opportunistic infection, and malignancy in IBD patients. ${ }^{5,10}$ This side effect on immune system then causes a higher burden of mortality on TNFinhibitor users. Therefore, there is still an urgent need for a novel biologic drug with mechanisms that are more effective and safer than TNF-inhibitor antibodies.

\section{LEUKOCYTE TRAFFICKING IN IBD}

IBD is a chronic inflammatory disease characterized by a chronic influx of leukocytes into affected intestinal tissues. ${ }^{1}$ Hence, it is theorized that blocking gut leukocyte trafficking leading to gut-specific immunosuppression can provide therapy with higher efficacy and better safety than TNF-inhibitor.

The process of leukocyte trafficking, regardless of target tissue or organ involve numerous tightly controlled steps. ${ }^{11,12}$ The first step being tethering and rolling of circulating leukocytes mediated by selectins. This initial process allows the circulating leukocytes to slow down on endothelial cells and become activated by chemokines. Subsequently, leukocytes activated 


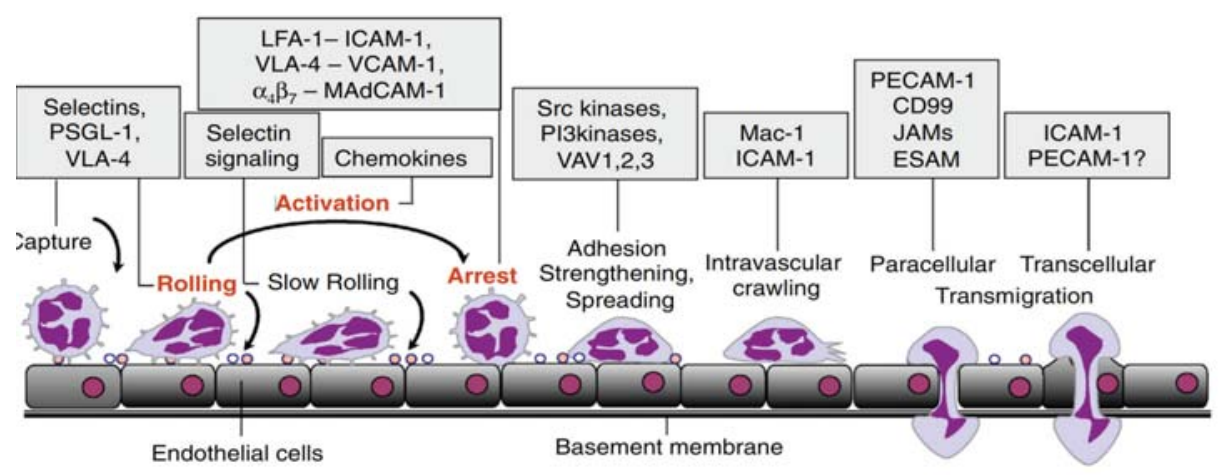

Figure 1. Leukocytes trafficking requires multiple steps that involve ligand interactions between leukocytes and endothelial cells. Removing the ligand interactions will disrupt leukocytes trafficking to target tissue. ${ }^{12}$

ESAM: endothelial cell-selective adhesion molecule; ICAM-1: intercellular adhesion molecule 1; JAM: junctional adhesion molecule; LFA-1: Iymphocyte function-associated antigen 1; Mac-1: macrophage antigen 1; MadCAM-1: mucosal addressin cell adhesion molecule-1; MLN: mucosal-associated lymph node; PECAM-1: platelet/endothelialcell adhesion molecule 1; PI3Ks: phosphoinositide 3-kinases; PSGL-1: P-selectin glycoprotein ligand 1; VCAM-1: vascular cell adhesion molecule 1; VLA-4: very late antigen 4

by chemokines undergoes conformational changes of adhesion receptors on the leukocytes called as integrins, which are a group of heterodimeric proteins receptors on cell surfaces that can be up-regulated in response to pro-inflammatory cytokines. The conformational changes on integrins forms high affinity bonds on endothelial cell immunoglobulin superfamily adhesion receptors such as intercellular cell adhesion molecule [ICAM]-1, mucosal vascular addressin cell adhesion molecule [MAdCAM]-1, and vascular cell adhesion molecule [VCAM]-1 which leads to firms and strong adhesion of leukocytes to endothelial cells. ${ }^{11}$ The adhered leukocytes will then finally transmigrate to the target tissue after further chemokines signaling.

Integrin is composed of $\alpha$ and $\beta$ subunits. Currently, in human, there are 24 known integrin heterodimers combination made up of $18 \alpha$ subunits and $8 \beta$ subunits which are then grouped according to cell type or ligand specificity such as leukocytes receptors, collagen receptors, arginine-glycine-aspartic acid [RGD] receptors, and laminin receptors. ${ }^{13}$ Interestingly, different leukocytes type express and upregulate different integrin receptor subunits. ${ }^{14,15}$ Furthermore, the target tissue where leukocytes migrate also affects the type of integrins used by leukocytes. For example, $\alpha 4 \beta 7$ integrin combination is expressed at moderate levels by naïve T cells while $\alpha 4 \beta 1$ integrin is expressed by many classes of leukocytes as this integrin combination plays a vital role in leukocyte tethering and rolling. ${ }^{14,15}$

Unique to gut endothelial vessels is high expression of MAdCAM-1. Additionally, gut-associated lymphoid tissue (GALT) and lamina propria are also rich in MAdCAM-1 expression. ${ }^{17}$ MAdCAM-1 through highaffinity bond on $\alpha 4 \beta 7$ integrin facilitate gut leukocyte tethering and rolling, especially when gut endothelial

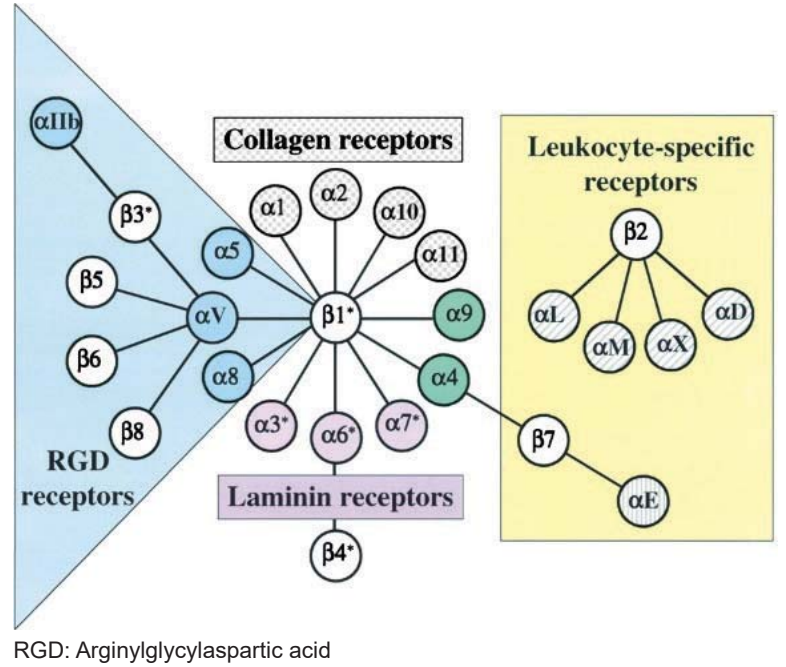

Figure 2. Possible pairing of Integrin heterodimer ${ }^{16}$

cells has reduced expression of selectins. As a result, without $\alpha 4 \beta 7$ integrin, lymphocytes have reduced capability to migrate to gut tissue. Other integrin that plays a role in gut leukocyte trafficking include $\alpha 4 \beta 1$ integrin that binds with VCAM- 1 . However, unlike MAdCAM-1, VCAM-1 is not gut selective and expressed in other tissues such as central nervous system (CNS). ${ }^{15,17}$

The role of $\alpha E \beta 7$ is also important since the migrated lymphocytes in the intestine will then upregulate $\alpha \mathrm{E} \beta 7$ integrin expression which promotes retention of lymphocytes through E-cadherin within intraepithelial compartment and lamina propria. ${ }^{15}$ Therefore, selective blocking of gut lymphocyte trafficking through integrins receptors can revolutionize treatment of IBD and is a promising therapeutic strategy in IBD. Currently, there are many anti-integrins approved by FDA or undergoing clinical trials. 
Table 1. Summary of anti-Integrin drugs

\begin{tabular}{|c|c|c|c|c|c|}
\hline Drug & Molecule & Target & Route & Clinical studies & Disease \\
\hline Natalizumab & Monoclonal antibody & $\alpha 4$ integrin & intravenous & $\begin{array}{l}\text { ENCORE } \\
\text { VARSITY }\end{array}$ & CD \\
\hline AJM300 & Small molecule & a4 integrin & oral & Phase IIA & UC \\
\hline Vedolizumab & Monoclonal antibody & $\alpha 4 \beta 7$ integrin & Intravenous & $\begin{array}{l}\text { GEMINI I } \\
\text { GEMINI II } \\
\text { GEMINI III } \\
\text { VARSITY }\end{array}$ & $\begin{array}{l}U C \\
C D \\
C D\end{array}$ \\
\hline Abrilumab & Monoclonal antibody & $\alpha 4 \beta 7$ integrin & Subcutaneous & $\begin{array}{l}\text { Phase IIB } \\
\text { Phase IIB }\end{array}$ & $\begin{array}{l}U C \\
C D\end{array}$ \\
\hline Etrolizumab & Monoclonal antibody & $\beta 7$ integrin & $\begin{array}{l}\text { Intravenous or } \\
\text { subcutaneous }\end{array}$ & $\begin{array}{l}\text { EUCALYPTUS } \\
\text { BERGAMOT } \\
\text { HICKORY }\end{array}$ & $\begin{array}{l}\text { UC } \\
C D \\
C D\end{array}$ \\
\hline $\begin{array}{l}\text { Ontamalimab (PF- } \\
\text { 00547659) }\end{array}$ & Monoclonal antibody & MAdCAM-1 & $\begin{array}{l}\text { Intravenous or } \\
\text { subcutaneous }\end{array}$ & $\begin{array}{l}\text { TURANDOT } \\
\text { OPERA }\end{array}$ & $\begin{array}{l}\text { UC } \\
\text { CD }\end{array}$ \\
\hline
\end{tabular}

CD: Crohn's disease, MadCAM-1: mucosal addressin cell adhesion molecule-1, UC: ulcerative colitis.

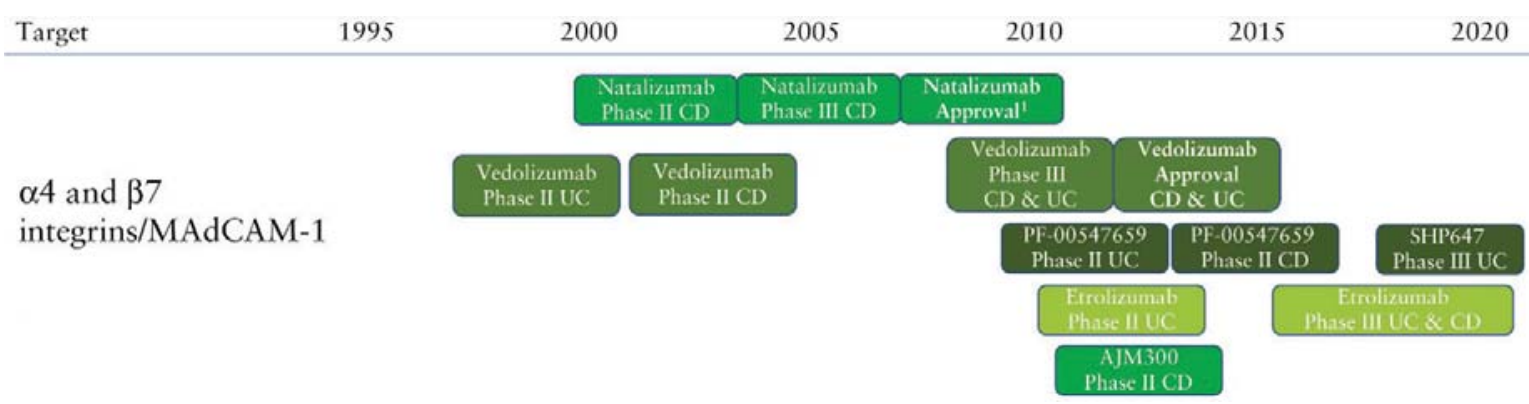

Figure 3. Timeline of anti-integrin drugs ${ }^{18}$

\section{NATALIZUMAB}

Natalizumab is a humanized monoclonal IgG4 antibody against $\alpha 4$ integrin subunit, previously used for relapsing multiple sclerosis. A phase II study in 1999 showed that natalizumab reduced CD4 T cells, CD8 T cells in cerebrospinal fluid of multiple sclerosis patients. ${ }^{19}$ Significant reduction of multiple sclerosis relapses was observed in following phase III trial. ${ }^{20}$ The drug was approved for monotherapy treatment in relapsing multiple sclerosis only for it to be withdrawn in February 2005 due to fatal progressive multifocal leukoencephalopathy (PML) by John Cunningham (JC) virus reactivation.

Natalizumab is able to block both $\alpha 4 \beta 1$ and $\alpha 4 \beta 7$ integrin on leukocytes, which actually provides a fatal flaw to natalizumab. ${ }^{21} \mathrm{~A} 4 \beta 1$ integrin has a role in central nervous system leukocyte trafficking and by blocking $\alpha 4 \beta 1$ integrin, natalizumab therefore inhibit non-gut leukocyte trafficking causing natalizumab to be associated with PML which led to its withdrawal. ${ }^{21}$ However, many patients lobbied for the drug to be reintroduced as many patients felt they benefited from natalizumab. Due to this, natalizumab was reintroduced but require tight monitoring and evaluation of patient prior JC virus status.

Natalizumab was then tested for IBD. In terms of effectiveness for IBD, natalizumab showed benefits of clinical response and clinical remission when compared to placebo. A phase III trial, Crohn's disease Response and Remission (ENCORE) trial recruited 509 Crohn's disease patients with inclusion criteria of moderate-tosevere activity and elevated C-reactive protein (CRP) $(>0.287 \mathrm{mg} / \mathrm{dL}){ }^{22}$ The patients were then divided into several groups receiving either placebo or natalizumab given by intravenous injection at weeks 0,4 , and 8 . The result of the study showed that at week 8 and week 12, percentage of sustained clinical remission was higher in natalizumab group than placebo group with $26 \%$ vs $16 \%(p=0.002)$. Other clinical trial such as ENACT-2 showed that group receiving natalizumab $300 \mathrm{mg}$ I.V every month had higher clinical remission, at $44 \%$, than in the placebo group, at $26 \%[p=0.003]{ }^{23}$ Based on these data, it was concluded that natalizumab is effective for induction and remission in active CD patients.

Both clinical trials also showed that the risk of developing PML is approximately 1 case for every 1000 patients after an average of 17.9 months natalizumab treatment. ${ }^{22,23}$ Due to this, FDA only approves the drug for moderate to severe $\mathrm{CD}$ patients that are unresponsive to conventional treatment of TNF inhibitors. However, European Medicines Agency (EMA) does not approve its use due to lack of benefit/ risk ratio. 


\section{AJM300}

AJM300 is an oral $\alpha 4$ integrin inhibitor currently evaluated for use in UC. The efficacy and safety of AJM300 was evaluated in a double-blind, placebocontrolled phase IIA clinical trial involving 102 moderately active UC patients unresponsive to steroid or mesalazine. ${ }^{24}$ The trial divided patients into placebo group and group receiving $960 \mathrm{mg}$ of AJM300 three times daily. Primary endpoint was clinical response while the secondary endpoint was clinical remission.

The trial showed that the group receiving $960 \mathrm{mg}$ of AJM300 orally 3 times each day had significantly higher clinical response, at $62.7 \%$, than the placebo group, at $25.5 \%(\mathrm{p}=0.0002) .{ }^{24}$ Furthermore, the clinical remission was also higher in the treatment group with $23.5 \%$ vs $3.9 \%(p=0.0099)$. Use of AJM300 also resulted in higher mucosal healing rate of $58.8 \%$ in AJM300 group than $29.4 \%$ in placebo group $(p=0.0099) .{ }^{24}$ In this clinical trial, no serious adverse events such as PML occurred. ${ }^{24}$ However, it should be noted that this clinical trial had short duration and small number of subjects. Therefore, longer duration trials with higher number of subjects are needed to confirm the safety of AJM300 as it is also a non-gut selective anti-integrin.

\section{VEDOLIZUMAB}

Vedolizumab (VDZ) is a humanized monoclonal IgG1 antibody that binds only $\alpha 4 \beta 7$-integrin. VDZ was developed due to the safety issue and non-gut selectivity of natalizumab. VDZ offers the advantage of selective intestinal leukocyte blocking, limiting its side effects on CNS immunity. ${ }^{25}$ Evidence of VDZ not affecting CNS immunity comes from a study where healthy volunteers were injected with VDZ and observation of cerebrospinal fluid taken 5 weeks later showed no change in cerebrospinal fluid lymphocyte counts. ${ }^{26}$ Additionally, since VDZ is gut-selective, VDZ is not associated with side effects from TNF inhibitors, corticosteroids, and conventional immunosuppressive such as azathioprine or methotrexate.

Efficacy and safety of VDZ as induction and maintenance therapy in IBD were evaluated in phase III GEMINI trials. The GEMINI trials were randomized, double blind, placebo-controlled trials which were divided into two trails as follows, GEMINI I for UC and GEMINI II for CD. ${ }^{27,28}$ Both the trials recruited patients with age from 18-80 years old with active IBD. Both trials concluded that VDZ is effective as induction and maintenance therapy for both UC and CD. However, later on, GEMINI III trial did not reach statistical significance over placebo for its primary endpoint of clinical remission at week $6 .^{29}$ The data from GEMINI III trial shows possibility that the failure to reach statistical significance can be attributed to a higher proportion of patients having prior TNFinhibitor failure and the trial using upper bound Crohn's Disease Activity Index (CDAI) score of 400 for patient inclusion criteria in GEMINI III. ${ }^{29}$

Subsequent post-hoc analyst of the GEMINI trials showed that prior use of TNF-inhibitor does indeed affect VDZ response rate. ${ }^{30}$ In subgroup of TNFinhibitor failure patients, there was no statistically significant difference at week 6 between VDZ(15.2\%) and placebo $(12.1 \%)$ with $\mathrm{p}=.433(\mathrm{RR}=1.2 ; 95 \%$ CI: 0.7-2.2) ${ }^{29}$ Meanwhile, in TNF-inhibitor naive group, VDZ treatment achieved statistically significant clinical remission than placebo at week 6 (Figure 4.) However, at week 10 both TNF-inhibitor failure group and TNF-inhibitor naïve group achieve significant clinical remission. VDZ may have a more pronounced effect on TNF-naive patients as the patient population with prior use of TNF-inhibitor had higher rates of longer disease duration, prior surgery, and higher inflammatory marker baseline. Therefore, TNFinhibitor failure group represents patients with higher disease severity and disease progression.

Table 2. Summary of GEMINI trials $\mathbf{s}^{27-29}$

\begin{tabular}{|c|c|c|c|c|c|}
\hline Study & $\mathrm{N}$ (patients) & Disease & Prior TNF Failure & Primary Endpoint & Secondary Endpoint \\
\hline \multirow[t]{2}{*}{ GEMINI 1} & 374 & UC & $40 \%$ & Response week $647 \%(p<0.0001)$ & $\begin{array}{c}\text { Remission week } 6 \\
17 \%(p<0.0001)\end{array}$ \\
\hline & & & & Remission week 52 42\% $(p<0.0001)$ & $\begin{array}{c}\text { Mucosal healing week } 6 \\
41 \%(p=0.0012)\end{array}$ \\
\hline \multirow[t]{2}{*}{ GEMINI II } & 368 & CD & $57.8 \%$ & $\begin{array}{l}\text { Remission week } 6 \\
15 \%(p=0.021)\end{array}$ & $\begin{array}{c}\text { Corticosteroid free remission } \\
32 \%(p<0.05)\end{array}$ \\
\hline & & & & $\begin{array}{l}\text { Remission week } 52 \\
39 \%(p<0.001)\end{array}$ & \\
\hline GEMINI III & 315 & CD & $76 \%$ & $\begin{array}{l}\text { Remission Week } 6 \\
15 \%(p=0.43)\end{array}$ & $\begin{array}{c}\text { Remission week } 10 \\
27 \%(p=0.0012)\end{array}$ \\
\hline
\end{tabular}

CD: Crohn's Disease; GEMINI I, Vedolizumab as Induction and Maintenance Therapy for Ulcerative Colitis; GEMINI II, Vedolizumab as Induction and Maintenance Therapy for Crohn's Disease; GEMINI III, Effects of vedolizumab induction therapy for patients with Crohn's disease in whom tumor necrosis factor antagonist treatment failed; TNF: tumor necrosis factor; UC: ulcerative colitis 


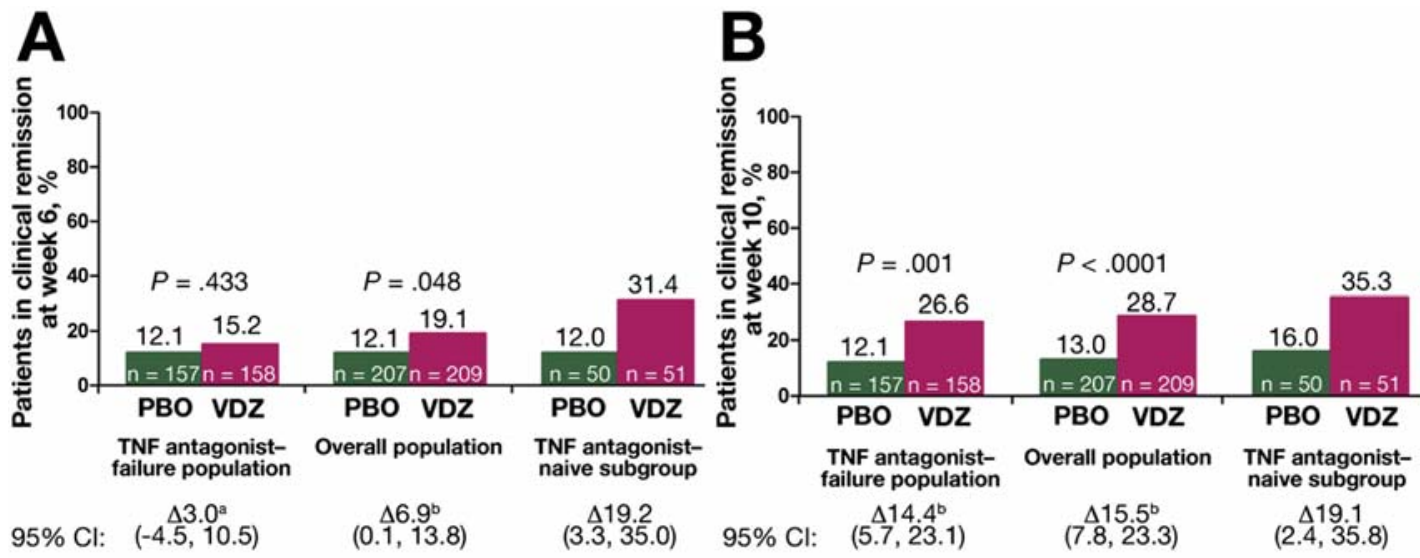

PBO, placebo; TNF, Tumor Necrosis Factor; VDZ, vedolizumab

Figure 4. Comparison of clinical remission between TNF-inhibitor failure group and TNF-inhibitor naïve group. ${ }^{29}$

Since VDZ only blocks $\alpha 4 \beta 7$-integrin, it is hypothesized that VDZ will not cause PML. The 5-year-integrated data analysis by Colombel et al, from six clinical trials with a total of 2830 patients confirmed that no PML cases have been observed. ${ }^{30}$ Meanwhile, the incidence rates of serious infections were similar for vedolizumab and placebo. Less than $1 \%$ patient had to discontinue the VDZ treatment due to serious infection. Similar finding was observed in post-marketing cohort studies after VDC was approved for use in 2014. ${ }^{31}$ However, due to gut selectivity of VDZ, there are some concerns of gastrointestinal infection, notably Clostridium difficile infections. Meta-analysis from post-marketing cohort studies showed that Clostridium difficile infections occurred on $2.1 \%$ of VDZ-exposed patients. ${ }^{31}$

For the malignancy rate, there was no statistically significant elevation of malignancy rate in VDZ group compared to placebo in clinical trials. ${ }^{27,28}$ Although the trials provided indications that VDZ is safe, these data have insufficient power and not enough duration to draw conclusions about the risk of malignancy on VDZ. As a result, long-term safety trials are needed to assess risk of malignancy from prolonged use of VDZ. VDZ was subsequently approved for clinical use by the FDA and EMA for moderate to severe UC and CD adult patients who are not responsive to conventional treatments or TNF inhibitors.

A head-to-head trial of vedolizumab versus adalimumab for Moderate to Severe UC was performed from July 2015 to January 2019 with 769 patients. ${ }^{32}$ This trial included patients exposed to previous TNFinhibitor up to $25 \%$. Clinical remission at week 52 is VDZ group was higher than adalimumab group (31.3\% vs. $22.5 \% ; p=0.006$ ). Additional endpoints such as endoscopic improvement was also better with VDZ group, however, there was no significant difference in corticosteroid-free clinical remission between two

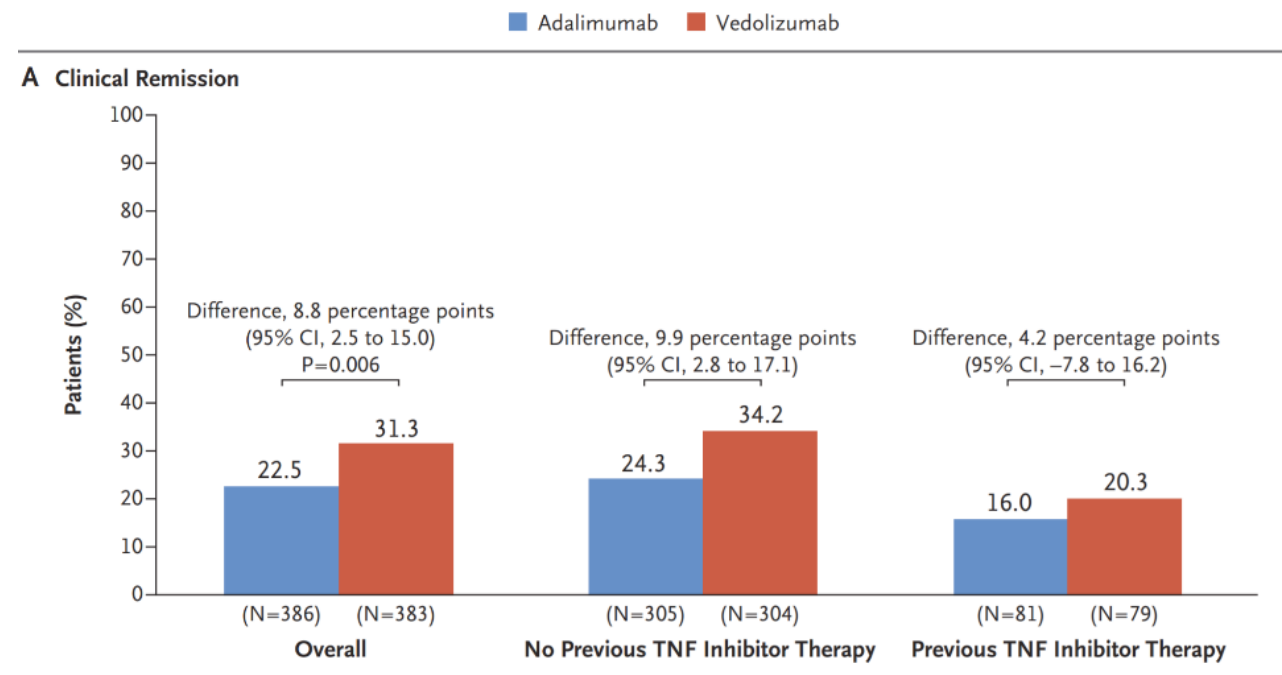

Figure 5. Vedolizumab therapy provided superior clinical remission than adalimubab ${ }^{32}$ 
groups. The incidence rates of infection were 23.4 and 34.6 events per 100 patient-years in VDZ group and adalimumab group respectively. ${ }^{32}$ This trial showed that VDZ is both more efficacious and safer than adalimumab.

\section{ABRILUMAB}

Abrilumab is a human monoclonal igG2 antibody for $\alpha 4 \beta 7$ integrin. Unlike VDZ, abrilumab is designed for subcutaneous administration, which may provide practical advantage for patients over intravenous infusion. ${ }^{33}$

A phase IIb randomized and placebo-controlled trial by Sandborn et al. was conducted to evaluate the efficacy and safety of abrilumab in 354 moderateto-severe UC patients. ${ }^{33}$ All the patients included in the trial exhibited no response or loss of response to TNF inhibitor, immunomodulators, or corticosteroid therapy. The patients were then divided into a placebo group, groups receiving subcutaneous abrilumab 7, 21, or $70 \mathrm{mg}$ at weeks 0,2 , and 4 , and a group receiving a single subcutaneous $210 \mathrm{mg}$ dose of abrilumab. The primary endpoint measured was remission rate at week 8 and the result showed that only abrilumab $70 \mathrm{mg}$ (p $=0.021)$ and abrilumab $210 \mathrm{mg}(\mathrm{p}=0.030)$ had higher clinical remission rates than the placebo group. In terms of safety, there was no PML through week $24 .{ }^{33}$

Another phase IIb with 45 UC patients was conducted in Japan. ${ }^{34}$ Despite no statistical analysis were made, this trial showed that $70 \mathrm{mg}$ is the minimal dose necessary to provide numerically better clinical remission when compared to placebo group, an observation similar in trial by Sandborn et al. ${ }^{33,34}$

\section{ETROLIZUMAB}

Etrolizumab is a humanized monoclonal IgG1 antibody that binds $\beta 7$ subunit of integrin. Etrolizumab therefore blocks $\alpha 4 \beta 7 / M A d C A M-1$ mediated leukocyte trafficking and $\alpha \mathrm{E} \beta 7$ integrin/E-cadherin interaction that play a role in intestinal intraepithelial compartment lymphocyte retention. ${ }^{35}$ Hence, etrolizumab has a broader action than anti- $\alpha 4 \beta 7$ integrin but maintaining gut-selectivity.

EUCALYPTUS is a phase II double-blind, randomised, placebo-controlled study published in 2014 that assessed the efficacy and safety of etrolizumab on 124 moderate-to-severe UC patients unresponsive to conventional therapy. ${ }^{35}$ The patients were randomly assigned in a 1:1:1 ratio into three groups. The first is the placebo group, then a group administered $100 \mathrm{mg}$ of subcutaneous etrolizumab at weeks 0,4 , and 8 , and lastly, the final group was given subcutaneous etrolizumab $420 \mathrm{mg}$ loading dose which was followed by subcutaneous doses of $300 \mathrm{mg}$. The primary endpoint measured was clinical remission at week 10 . Based from the trial, $20.5 \%$ in the etrolizumab $100 \mathrm{mg}$ group $(\mathrm{p}=0.004)$, and $10.3 \%$ in the etrolizumab $420 \mathrm{mg}$ group $(\mathrm{p}=0.048)$ had higher clinical remission than in the placebo group. ${ }^{35}$ Similar to previous studies, the subgroup analysis showed that clinical remission rates were higher in TNF-inhibitor naive patients than TNF-inhibitor failure patients. ${ }^{35}$

No cases of serious infection were observed in etrolizumab treated groups. However, there was a pattern that showed influenza-like illness, arthralgia, and rash occurred more frequently in the etrolizumab treated group than the placebo group. ${ }^{35}$ It should be noted that safety profile for etrolizumab in EUCALYPTUS is based on short-term study with low numbers of patients, thus further studies with longer duration and larger patients number were needed.

A phase III trial was also conducted to assess efficacy and safety of etrolizumab in 300 moderate to severe CD patients. ${ }^{36}$ The trial showed that both etrolizumab $105 \mathrm{mg}$ and $210 \mathrm{mg}$ achieved significantly better clinical remission than placebo group in week 6,10 , and 14. No significant difference in adverse events were observed between etrolizumab groups and placebo group. ${ }^{36}$ Currently, there are 5 other ongoing phase III randomized controlled trials on etrolizumab.

\section{ONTAMALIMAB}

MAdCAM-1 is the endothelial ligand for $a 4 b 7$ integrin and it is expressed predominantly in the intestine. Interestingly, the expression MAdCAM-1 on gut endothelial is increased in IBD. ${ }^{37}$ Several murine studies showed that inhibition of MAdCAM-1 resulted in reduction of lymphocyte recruitment and colonic inflammation. ${ }^{38,39}$ As a result of these observations, ontamalimab, a fully human monoclonal antiMAdCAM-1 antibody which block endothelial CAM was developed.

Ontamalimab is currently being investigated in a large-scale phase III study for IBD. The phase II TURANDOT trial had previously revealed significantly higher rates of clinical remission with ontamalimab in ulcerative colitis patients at week $12 .{ }^{40}$ However, the phase II OPERA trial showed that ontamalimab failed to achieve primary endpoint of 
clinical response at week 8 or 12 in CD patients despite pharmacological evidence of soluble MAdCAM-1 reduction and increase of circulating T cells. ${ }^{41}$ This conflicting result may be explained transmural nature of $\mathrm{CD}$ which may cause ontamalimab to require longer duration to achieve clinical effect. Currently, it is unknown whether anti-a4b7 and anti-MAdCAM-1 antibodies produce identical effect.

\section{CONCLUSION}

TNF-inhibitor as a biologic agent revolutionized IBD treatment by its superior therapeutic effects compared to conventional treatments. However, there are still several limitations from TNF-inhibitor, most notably safety issue such as infection and malignancy. Furthermore, some patients are unresponsive to TNF-inhibitor. Due to these limitations and newer understanding of IBD pathophysiology, anti-integrin agents as new biologic agent was developed.

Anti-integrin agents which work by inhibiting extravasation of circulating leukocytes to intestinal tissue have been shown in numerous clinical trials to be effective and safe in IBD management. Currently direct head-to-head trials between anti-integrin agents and TNF-inhibitor are needed to confirm whether anti-integrin provides superior benefit than TNFinhibitor as induction and maintenance therapy in adult IBD patients. However, safety data from available anti-integrin trials predict that anti-integrins agents to be safer than TNF-inhibitor clinically. Except natalizumab, none of the other anti-integrin drugs have significant risk for PML. In the future, anti-integrin is expected to be more common in clinical practice and become a step in personalized medicine.

\section{REFERENCES}

1. Nemati S, Teimourian S. An Overview of inflammatory bowel disease: general consideration and genetic screening approach in diagnosis of early onset subsets. Middle East J Dig Dis 2017;9:69-80.

2. Ng SC. Emerging trends of inflammatory bowel disease in Asia. Gastroenterol Hepatol 2016;12:193-6.

3. Arseneau K, Cominelli F. Targeting leukocyte trafficking for the treatment of inflammatory bowel disease. Clin Pharmacol Ther 2014;97:22-8

4. Guo Y, Lu N, Bai A. Clinical use and mechanisms of Infliximab treatment on inflammatory bowel disease: a recent update. BioMed Res Int 2013;2013:581631

5. Adegbola SO, Sahnan K, Warusavitarne J, Hart A, Tozer P. Anti-TNF therapy in Crohn's disease. Int J Mol 2018;19:2244.

6. Singh S, George J, Boland BS, Vande Casteele N, Sandborn
WJ. Primary non-response to tumor necrosis factor antagonists is associated with inferior response to second-line biologics in patients with inflammatory bowel diseases: a systematic review and meta-analysis. J Crohns Colitis 2018;12:635-43.

7. Gisbert JP, Panés J. Loss of response and requirement of infliximab dose intensification in Crohn's disease: a review. Am J Gastroenterol 2009;104:760-7.

8. Roda G, Jharap B, Neeraj N, Colombel J-F. Loss of response to anti-TNFs: definition, epidemiology, and management. Clin Transl Gastroenterol 2016;7:e135.

9. Billiet T, Rutgeerts P, Ferrante M, Van Assche G, Vermeire S. Targeting TNF- $\alpha$ for the treatment of inflammatory bowel disease. Expert Opin Biol Ther 2014;14:75-101.

10. Connor V. Anti-TNF therapies: a comprehensive analysis of adverse effects associated with immunosuppression. Rheumatol Int 2011;31:327-37.

11. Salas A, Shimaoka M, Kogan AN, Harwood C, von Andrian UH, Springer TA. Rolling adhesion through an extended conformation of integrin alphaLbeta2 and relation to alpha I and beta I-like domain interaction. Immunity 2004;20:393406.

12. Mosli MH, Rivera-Nieves J, Feagan BG. T-cell trafficking and anti-adhesion strategies in inflammatory bowel disease: current and future prospects. Drugs 2014;74:297-311.

13. Campbell ID, Humphries MJ. Integrin structure, activation, and interactions. Cold Spring Harb Perspect Biol 2011;3:a004994

14. Bargatze RF, Jutila MA, Butcher EC. Distinct roles of L-selectin and integrins alpha 4 beta 7 and LFA-1 in lymphocyte homing to Peyer's patch-HEV in situ: the multistep model confirmed and refined. Immunity 1995;3:99-108.

15. Lamb CA, O’Byrne S, Keir ME, Butcher EC. Gut-selective Integrin-targeted therapies for inflammatory bowel disease. J Crohns Colitis 2018;12:S653-68.

16. Hynes RO. Integrins: bidirectional, allosteric signaling machines. Cell 2002;110:673-87.

17. Briskin M, Winsor-Hines D, Shyjan A, Cochran N, Bloom $\mathrm{S}$, Wilson J, et al. Human mucosal addressin cell adhesion molecule-1 is preferentially expressed in intestinal tract and associated lymphoid tissue. Am J Pathol 1997;151:97-110.

18. Panés J, Salas A. Past, present and future of therapeutic interventions targeting leukocyte trafficking in inflammatory bowel disease. J Crohns Colitis 2018;12:S633-40.

19. Sheremata WA, Vollmer TL, Stone LA, Willmer-Hulme AJ, Koller M. A safety and pharmacokinetic study of intravenous natalizumab in patients with MS. Neurology1999;52:1072-4.

20. Miller DH, Khan OA, Sheremata WA, Blumhardt LD, Rice GPA, Libonati MA, et al. A controlled trial of natalizumab for relapsing multiple sclerosis. N Engl J Med 2003;348:15-23.

21. McCormack PL. Natalizumab: a review of its use in the management of relapsing-remitting multiple sclerosis. Drugs 2013;73:1463-81.

22. Targan SR, Feagan BG, Fedorak RN, Lashner BA, Panaccione $\mathrm{R}$, Present DH, et al. Natalizumab for the treatment of active Crohn's disease: results of the ENCORE Trial. Gastroenterology 2007;132:1672-83.

23. Sandborn WJ, Colombel JF, Enns R, Feagan BG, Hanauer SB, Lawrance IC, et al. Natalizumab induction and maintenance therapy for Crohn's disease. N Engl J Med 2005;353:1912-25.

24. Yoshimura N, Watanabe M, Motoya S, Tominaga K, Matsuoka K, Iwakiri R, et al. Safety and efficacy of AJM300, an oral antagonist of $\alpha 4$ Integrin, in induction therapy for patients with active ulcerative colitis - Gastroenterology 2015;149:1775-83

25. Fedyk ER, Wyant T, Li-li Y, Csizmadia V, Burke K, Yang H, et 
al. Exclusive antagonism of the $\alpha 4 \beta 7$ Integrin by Vedolizumab confirms the gut-selectivity of this pathway in primates. Inflamm Bowel Dis 2012;18:2107-19.

26. Milch C, Wyant T, Xu J, Parikh A, Kent W, Fox I, et al. Vedolizumab, a monoclonal antibody to the gut homing $\alpha 4 \beta 7$ integrin, does not affect cerebrospinal fluid T-lymphocyte immunophenotype. J Neuroimmunol 2013;264:123-6.

27. Sandborn WJ, Feagan BG, Rutgeerts P, Hanauer S, Colombel J-F, Sands BE, et al. Vedolizumab as induction and maintenance therapy for Crohn's disease. N Engl J Med 2013;369:711-21.

28. Feagan BG, Rutgeerts P, Sands BE, Hanauer S, Colombel $\mathrm{J}-\mathrm{F}$, Sandborn WJ, et al. Vedolizumab as induction and maintenance therapy for ulcerative colitis. N Engl J Med. 2013;369:699-710.

29. Sands BE, Feagan BG, Rutgeerts P, Colombel J-F, Sandborn WJ, Sy R, et al. Effects of vedolizumab induction therapy for patients with Crohn's disease in whom tumor necrosis factor antagonist treatment failed. Gastroenterology 2014;147:618-627.e3.

30. Colombel J-F, Sands BE, Rutgeerts P, Sandborn W, Danese S, D'Haens G, et al. The safety of vedolizumab for ulcerative colitis and Crohn's disease. Gut 2017;66:839-51.

31. Bye WA, Jairath V, Travis SPL. Systematic review: the safety of vedolizumab for the treatment of inflammatory bowel disease. Aliment Pharmacol Ther 2017;46:3-15.

32. Sands BE, Peyrin-Biroulet L, Loftus EV, Danese S, Colombel $\mathrm{J}-\mathrm{F}$, Törüner $\mathrm{M}$, et al. Vedolizumab versus Adalimumab for moderate-to-severe ulcerative colitis. N Engl J Med 2019;381:1215-26.

33. Sandborn WJ, Cyrille M, Hansen MB, Feagan BG, lottus $\mathrm{EV}$, et al. Efficacy and safety of Abrilumab in a randomized, placebo-controlled trial for moderate-to-severe ulcerative colitis. Gastroenterology 2019;156:946-57.

34. Hibi T, Motoya S, Ashida T, Sai S, Sameshima Y, Nakamura S, et al. Efficacy and safety of abrilumab, an $\alpha 4 \beta 7$ integrin inhibitor, in Japanese patients with moderate-to-severe ulcerative colitis: a phase II study. Intest Res 2019;17:375-86.

35. Vermeire S, O’Byrne S, Keir M, Williams M, Lu TT, Mansfield $\mathrm{JC}$, et al. Etrolizumab as induction therapy for ulcerative colitis: a randomised, controlled, phase 2 trial. The Lancet 2014;384:309-18.

36. Sandborn W, Panes J, Jones J, Hassanali A, Jacob R, Sharafali $\mathrm{Z}$, et al. Etrolizumab as induction therapy in moderate to severe Crohn. Am J Gastroenterol 2018; 113:pS3.

37. Souza HS, Elia CC, Spencer J, MacDonald TT. Expression of lymphocyte-endothelial receptor-ligand pairs, alpha4beta7/ MAdCAM-1 and OX40/OX40 ligand in the colon and jejunum of patients with inflammatory bowel disease. Gut 1999;45:856-63.

38. Picarella D, Hurlbut P, Rottman J, Shi X, Butcher E, Ringler DJ. Monoclonal antibodies specific for beta 7 integrin and mucosal addressin cell adhesion molecule-1 (MAdCAM-1) reduce inflammation in the colon of scid mice reconstituted with CD45RBhigh CD4+ T cells. J Immunol Baltim Md 1997;158:2099-106.

39. Kato S, Hokari R, Matsuzaki K, Iwai A, Kawaguchi A, Nagao S, et al. Amelioration of murine experimental colitis by inhibition of mucosal addressin cell adhesion molecule-1. J Pharmacol Exp Ther 2000;295:183-9.

40. Vermeire S, Sandborn WJ, Danese S, Hébuterne X, Salzberg BA, Klopocka M, et al. Anti-MAdCAM antibody (PF00547659) for ulcerative colitis (TURANDOT): a phase 2, randomised, double-blind, placebo-controlled trial. Lancet
Lond Engl 2017;390:135-44.

41. Sandborn WJ, Lee SD, Tarabar D, Louis E, Klopocka M, Klaus J, et al. Phase II evaluation of anti-MAdCAM antibody PF-00547659 in the treatment of Crohn's disease: report of the OPERA study. Gut 2018;67:1824-35. 